\title{
Linking Human Dignity, Vulnerability and Virtue Ethics
}

\author{
James F. Keenan, SJ \\ Theology Department, Boston College, Boston, MA, USA \\ james.keenan.2@bc.edu
}

\begin{abstract}
An ethics of vulnerability, that develops out of an imago Dei/human dignity presupposition, can provide a foundation for a virtue ethics that orients us toward the right responsiveness to contemporary challenges. It explores a vulnerability rooted in imago Dei language and then further develops a vulnerability foundation that is based not primarily on need but on capacity. It concludes offering particular virtues (humility, vigilance, mercy and hospitality) that help in the practice of recognizing human dignity.
\end{abstract}

\section{Keywords}

capacity - dignity - hospitality - humility - mercy - precarity - vigilance - vulnerability

Human dignity, grounded in the imago Dei tradition, expands and offers guidelines for personal and communal flourishing through the virtue ethics tradition. Here I would like to show how an ethics of vulnerability, that develops out of an imago Dei/human dignity presupposition, can provide a foundation for a virtue ethics that orients us toward the right responsiveness to contemporary challenges. I will first explore vulnerability rooted in imago Dei language and then further develop a vulnerability foundation, and conclude offering particular virtues (humility, vigilance, mercy and hospitality) that help in the practice of recognizing human dignity. 
In the twenty-first chapter of T.H. White's wonderful The Once and Future King, ${ }^{1}$ we read a memorable account of creation that captures human vulnerability beautifully. On the fifth and sixth day of creation, God gathers all the embryos of each and every species of animal life and offers each embryo a wish for something extra. The giraffe embryo gets a long neck for tree food, the porcupine asks for quills for protection, and so it goes for the entire animal kingdom. The last embryo is the human, who when asked by God what he wants, responds, "I think that You made me in the shape which I now have for reasons best known to Yourselves, and that it would be rude to change [...]. I will stay a defenceless embryo all my life." God is delighted and lets the human embryo have no particular protection, to be the most vulnerable of all newborns and says, "As for you, Man [...] You will look like an embryo till they bury you."

White's vision of the human embryo as the bearer of human vulnerability is remarkable, for behind this decision is the assumption that we are made in God's image and that if we are vulnerable, so is God. And so White concludes his account with God disclosing to the human, "Adam", "Eternally undeveloped, you will always remain potential in Our image, able to see some of Our sorrows and to feel some of Our joys. We are partly sorry for you, Man, but partly hopeful." Human dignity, rooted in the image of God, participates in the vulnerability of God.

In 2005 the Irish moral theologian Enda McDonagh introduced us to the theology of vulnerability in a book called Vulnerable to the Holy: In Faith, Morality and Art. ${ }^{2}$ McDonagh began his treatment on vulnerability not with the human, but with God. God reveals to us God's self as vulnerable by the very act of creation, in which God lets the light be, life be, nature be, animal life and human life be. McDonagh adds this is a God who lets go and takes risks. ${ }^{3}$ Notably, McDonagh sees in Mary's reply to the annunciation, "Be it done unto me according to thy Word", another moment of risk, of letting go, that at once engages the divine initiative. The riskiness of the Creation extends into the Incarnation.

Implicit in this then is the assumption that if God is vulnerable, then we in God's image are made vulnerable. In all this vulnerability, there is great risk.

1 White, The Once and Future King.

2 McDonagh, Vulnerable to the Holy.

3 McDonagh, Vulnerable to the Holy, p. 12-20. 
God take risks in all that God does because God is vulnerable and God's vulnerability informs our own.

Similarities to McDonagh's claims can be found in a variety of other works of theology. Before the discourse on vulnerability developed, in fact, before it was even articulated, Abraham Heschel wrote about a divine "sympathy" in his work on prophets and divine pathos; this sympathy captures in these divine sensibilities a vulnerability that the prophets tangibly breathe when they echo the voice of God. Heschel writes:

An analysis of prophetic utterances shows that the fundamental experience of the prophet is a fellowship with the feelings of God, a sympathy with the divine pathos, a communion with the divine consciousness which comes about through the prophet's reflection of, or participation in, the divine pathos. The typical prophetic state of mind is one of being taken up into the heart of the divine pathos. Sympathy is the prophet's answer to inspiration, the correlative to revelation. Prophetic sympathy is a response to transcendent sensibility [...]. The emotional experience of the prophet becomes the focal point for the prophet's understanding of God. He lives not only his personal life, but also the life of God. The prophet hears God's voice and feels His heart. He tries to impart the pathos of the message together with its logos. As an imparter his soul overflows, speaking as he does out of the fullness of his sympathy. ${ }^{4}$

Vulnerable to the voice of God, the prophet receives the sensibility of that voice and in the very reception encounters and discovers the capacity to express the sympathy of God. Like the prophets, we too, when we are vulnerable to the holy, tap into that divine self-expression of sympathetic responsiveness.

These comments on vulnerability might surprise the reader who thinks of vulnerability primarily as the condition that raises alarm, concern, or the need to protect. When they read, for instance, the Good Samaritan parable, they think of the wounded man as vulnerable, whereas these others would think of the Good Samaritan as the one vulnerable to the condition of the wounded man. This inversion about vulnerability mirrors the inversion in the same parable about the question of the neighbor itself: in answering the question, who is my neighbor, we think at the beginning of the parable that the wounded man is the neighbor, but by the end we agree with the scribe that the neighbor is the one who shows mercy. In a similar way the neighbor has gone from being object of concern to being responsive agent. The concept of vulnerability in

4 Heschel, The Prophets, p. 25 et seq. 
contemporary literature has moved similarly from the wounded one to the responsive one.

This move is not a simple one; rather, it redeems the notion of vulnerability from being something to avoid to being something to express. Why and how did this happen? In a very fine book, The Ethics of Vulnerability: A Feminist Analysis of Social Life and Practice, Erinn C. Gilson considers the implications of a reductively negative view of vulnerability. ${ }^{5}$ She argues rightly that if vulnerability is only the object of concern and not the very condition for responsiveness, then we inevitably compromise our argument: relegating vulnerability singularly to a weakness effectively means making us wish ourselves to be anything but vulnerable so as to respond to those in need. She writes:

The meaning of vulnerability is commonly taken for granted and it is assumed that vulnerability is almost exclusively negative, equated with weakness, dependency, powerlessness, deficiency and passivity. This reductively negative view leads to problematic implications, imperilling ethical responsiveness to vulnerability, and so prevents the concept from possessing the normative value many theorists wish it to have. When vulnerability is regarded as weakness and, concomitantly, invulnerability is prized, attentiveness to one's own vulnerability and ethical response to vulnerable others remain out of reach goals. ${ }^{6}$

When we recognize that the word vulnerable does not mean being or having been wounded, but rather means being able to be wounded, then it means being exposed to the other; in this sense vulnerability is the human condition that allows me to encounter, receive, or respond to the other, it allows us to be aware of others and their dignity, to take risks in meeting and recognizing others.

Much of the contemporary discourse on vulnerability is indebted to Emmanuel Levinas for his appreciation of the human condition of recognizing the other. McDonagh acknowledges it, ${ }^{7}$ as does the renowned Belgian ethicist who brought Levinas into Catholic moral theology, Roger Burggraeve. ${ }^{8}$ In a new work by the Australian ethicist Daniel J. Fleming, we find an excellent summary of Levinas's contribution: "Levinas' foundational understanding is not, as is commonly suggested, something that proceeds from our understanding

5 Gilson, The Ethics of Vulnerability.

6 Gilson, The Ethics of Vulnerability, p. i. See also p. 31-38.

7 McDonagh, Vulnerable to the Holy, p. 7 et seq.

8 Burggraeve, The Wisdom of Love; Burggraeve, The Awakening to the Other. 
of what it means to be human but rather it is the very structure out of which the possibility for this process arises." Levinas's challenge is that our encounter with the other person precedes consciousness: because of this it also precedes the meaning we make of the encounter, the meaning we make of ourselves and the rational activity of making decisions regarding the nature of our response to this other person. ${ }^{9}$ Finally, the American philosopher Judith Butler gives an extraordinary rendition of Levinas's contributions in her Giving an Account of Oneself. ${ }^{10}$

It is Butler, as Gilson acknowledges, who has truly developed an ethics of vulnerability. ${ }^{11}$ In her own work, she recognizes how fundamentally "prior" vulnerability is, a point similar to the "precedence" that Levinas gave to it. Vulnerability precedes everything about being human. In theological language, the priority of vulnerability is precisely that ground on which the imago rests and from which it emanates. The divine enters the human through vulnerability, just as for Heschel the divine sensibilities is what makes us in God's image. Or another way, the covenant, which binds us to God, is as vulnerable as the bonds that bind us to one another.

On this priority, she writes, "ethical obligation not only depends upon our vulnerability to the claims of others but establishes us as creatures who are fundamentally defined by that ethical relation."12 Vulnerability is what defines and establishes us as creatures before God and as ethical among one another. Butler adds, "This ethical relation is not a virtue that I have or exercise; it is prior to any individual sense of self. It is not as discrete individuals that we honor this ethical relation. I am already bound to you, and this is what it means to be the self I am, receptive to you in ways that I cannot fully predict or control."13 Vulnerability is our nature; it is the condition for the possibility of our responding, of our being ethical. It precedes our decision, even what we once called the fundamental option. She writes,

You call upon me, and I answer. But if I answer, it was only because I was already answerable; that is, this susceptibility and vulnerability constitutes me at the most fundamental level and is there, we might say, prior to any deliberate decision to answer the call. In other words, one has to be

9 Fleming, Attentiveness to Vulnerability. Emphasis added.

10 Butler, Giving an Account of Oneself, p. 84-101.

11 Gilson, Thinking Vulnerability with Judith Butler, p. 40-71.

12 Butler, Precarious Life, p. 141; see for instance also p. 134-151. I want to thank James Hanvey for introducing me to these topics.

13 Butler, Precarious Life, p. 141 et seq. 
already capable of receiving the call before actually answering it. In this sense, ethical responsibility presupposes ethical responsiveness. ${ }^{14}$

Our vulnerability is what allows us to love.

We will see later in this essay other positions by Christian ethicists on vulnerability but here we could turn to moral development. Years ago in 1988, in reflecting on gender and domination, the psychoanalyst and feminist theorist Jessica Benjamin reflected on infancy and mutual recognition among infants. Mutual recognition is that central experience among infants when they are suddenly no longer the object of others' attention; the infant encounters others like her or him, a subject, if you will, among other subjects. Benjamin writes, "Mutual recognition is the most vulnerable point in the process of differentiation." She adds, "In mutual recognition, the subject accepts the premise that others are separate but nonetheless share like feelings and intentions." ${ }^{15}$ In this mutual recognition we grasp that it is our vulnerability to one another that makes us human.

Benjamin sought to explore ways of restoring mutual recognition as a defining key for understanding right relationship between the genders. In particular she was concerned with gender and the problem of why some men, in particular, turn to domination. She found that these males, as infants and then as children, were encouraged and led to abandon their own vulnerability and to develop instead a need to dominate. The process to develop domination, she argued, is a two-fold alienation. First, the male becomes alienated from his original vulnerable self. Second, he looks to dominate others, often women. In a more recent work in 2017, she turns again to mutual recognition and among other matters finds the language of vulnerability key for recuperating and restoring the experience of mutual recognition. ${ }^{16}$

These two scholars help us to appreciate more the reconciling and humanizing traits of vulnerability, helping us to see it as something that establishes for us as human beings the possibility to be relational and therefore moral. In effect, vulnerability is the capacity to be moral.

Still, the reader might be wondering about those persons, who like the wounded man in the Good Samaritan parable, have such a tangible vulnerability that they need urgent care. Here Butler offers the distinctiveness of precarity in terms of its relationship to vulnerability. Vulnerability allows oneself to be at risk in response to others; but we should not think that vulnerability

\footnotetext{
14 Butler, Precarious Life, p. 142.

15 Benjamin, The Bonds of Love, p. 53.

16 Benjamin, Beyond Doer and Done to.
} 
is always precarious. My openness to you is not always a fragile one, though I allow myself to be exposed to the other. In instances of responding to the other, I might still take risks, though even those risks themselves are not necessarily precarious.

Butler writes: "Precarity exposes our sociality, the fragile and necessary dimensions of our interdependency."17 Certainly, in being vulnerable, we have the capacity to encounter and respond to another whose vulnerability is precarious and we can, in our own vulnerability, enter into the precarity of another. But my vulnerability is often present to me and others without any precarity. I tend to think of precarity as being in an unstable situation. So though we all are vulnerable, not all experience precarity.

I find a turn to the Prodigal Son parable helpful. There the younger son's own precarity presents a good way of appreciating both concepts and in particular how they might be found in the Scriptures. In the beginning of that parable, we encounter the younger brother's rapid decline into precarity but the center of the parable turns to and focuses on the vulnerable one, the father who recognizes his son in the distance, embraces him, re-incorporates him, and begins the process of restoring all that was unstable, threatened, exposed, and jeopardized in the younger son. The same father remains vulnerable to his older son who does not suffer from precarity but from resentment. Let us not think, however, that the father is surprised by the older son's resentment. When he sees his younger son in the distance, he knows that his movement toward the younger son will trigger the older son's own insecurities. The father's vulnerability frees him to anchor both sons in his household. The stability in the story is the vulnerable father, as the precarious son returns and the resentful one tries to leave; the centrality of the story is the enduringly vigilant, attentive, and responsive father, who is so because he is vulnerable and is capable of not only embracing them but in entering one's precarity or the other's dominance.

Vulnerability plays itself out even more so in the Good Samaritan parable (Luke 10:29-37). We have already seen how the understanding of being neighbor shifts from one in need to one who is responsive; this parallels the shift of vulnerability from being precarious to being capacious. But there is another insight that we need to retrieve. Like the surprise ending, many of us forget that this parable was never understood primarily as a moral one. Rather, through allegory the parable becomes the Gospel in miniature, the Gospel of our redemption by Christ. Starting with Clement of Alexandria (ca.15o-ca. 215), then Origen (ca. 184-ca. 254), Ambrose (339-390), and finally Augustine (354-430),

17 Butler, Notes toward a Performative Theory of Assembly, p. 119; see also Butler, Precarious Life. 
the Good Samaritan parable is explained as the merciful narrative of our redemption. Later from Venerable Bede (673-735) to Martin Luther (1483-1546), preachers and theologians appropriate and modify the narrative.

The basic allegorical expression of the parable was this: the man who lies on the road is Adam, wounded (by sin), suffering outside the gates of Eden. The priest and the Levite, (the law and the prophets), are unable to do anything for Adam; they are not vulnerable to him. Along comes the Good Samaritan (Christ), a foreigner, one not from here, who vulnerably tends to Adam's wounds, takes him to the inn (the church), makes a down payment, leaves him in the inn (the Church), and promises to return for him (the second coming) when he will pay in full for the redemption and take him with him into his kingdom.

The parable then is first and foremost not a moral story about how we should treat others, but rather the central story of our own redemption, that is, what Christ has done for us. We are called, if you will, to a mutual recognition, of seeing in Christ the one who became vulnerable for us so that we might be saved. In him we recognize the image out of which we are made, the vulnerable one. Our dignity rooted in the imago Dei is rooted in vulnerability.

Like the Prodigal Son, the parable is about the scandal of our redemption; not how bad we are, but how vulnerable God in Jesus Christ is. In realizing how vulnerable God is, we recognize our own capacity for vulnerability, and therein discover the capacity and the call to go and do likewise, that is to practice mercy, which, from the Good Samaritan parable itself, I define as the willingness to enter into the chaos of another: mercy is the virtue of the vulnerable.

\section{The Virtues of Vulnerability}

This past year, Catholic Theological Ethics in the World Church held its third international conference in Sarajevo with 500 theological ethicists from 8o countries; Linda Hogan of Trinity College Dublin, an original chair of CTEWC, gave the final plenary proposing an ethics of vulnerability for a divided world. Following a host of moral theologians and philosophers, like Levinas, McDonagh, Burggraeve, Gilson, Butler, and Vincent LeClerq, ${ }^{18}$ she describes "vulnerability as a way of being, as the ground of our relationality, and as mode of social engagement." ${ }^{\text {"9 }}$

18 LeClerq, Blessed Are The Vulnerable.

19 Hogan, Vulnerability, p. 216. 
She finds promise in vulnerability and asks,

Can this existential experience of vulnerability be deployed in the service of a politics that unites rather than divides? This depends on whether this recognition of vulnerability can generate a new kind of conversation: about how we act in the world; about our ethical obligations towards each other; about how to oppose the conditions under which some lives are more vulnerable than others. ${ }^{20}$

She concludes,

Mutual dependence, shared vulnerability, these are elements of human experience that have rarely featured in the ways in which politics is constructed or ethical theories are framed. Indeed, much of our politics and ethics seems to be intent on foreclosing this recognition. And yet shared vulnerability and mutual dependence may be precisely the qualities that have a resonance with the individuals and communities world-wide who are struggling to find the grounds for the hope of shared future in a world divided. ${ }^{21}$

Along with others, ${ }^{22}$ Hogan amply shows how vulnerability could well animate the discourse regarding how we encounter human dignity across the world. Indeed, Hogan herself is one who has offered a significant and hope-filled apology for a human rights discourse, animated by the language of human dignity. Insisting that our expectations ought to be more modest and realistic, she suggests in her work, Keeping Faith with Human Rights, that human rights discourse can amply support our work to achieve greater equity universally. For her, vulnerability, human dignity, and human rights are mutually engaging and illuminating. ${ }^{23}$

Agreeing with Hogan, I would like to facilitate this type of discussion by expanding on how very particular virtues help us engage human vulnerability wherein we, through mutual recognition, get a glimpse of human dignity and therein choose to respond through the promotion of human rights so as to

\footnotetext{
$20 \quad$ Hogan, Vulnerability, p. 219.

21 Hogan, Vulnerability, p. 219 et seq.

22 More recently I have found these essays helpful: on the differing positions concerning vulnerability in general, Mathewes, Vulnerability and Political Theology, p. 165-184; and on the sovereign and fragile self, Haker, The Fragility of the Moral Self, p. 359-381.

23 Hogan, Keeping Faith with Human Rights.
} 
secure a more equitable distribution of those rights. I intend to see these virtues as building on one another, being not unlike a ladder of ascent.

The first virtue that supports a vulnerable treatment of human dignity is humility.

Vulnerability begins with humility, a redemptive humility, a humility burdened not with self-deprecation but rather with an unabashed selfunderstanding of what it really means for one to act in conscience - that is, to do good and avoid evil in accordance with God's will.

I believe that it is precisely a humble conscience that helps us to see our inter-relatedness, that helps us to see a mutual recognition, where we are all inter-dependent in the further realization of human dignity. Throughout the Scriptures, we discover a vulnerable freedom that allows us to see our place among the people of God.

Humility keeps us grounded. Inasmuch as the word humility derives from humus, meaning soil or dirt, humility keeps us close to the moral terrain in which we find ourselves. A humble conscience keeps us alert to our environment, our neighbor in need, our own responsibilities, and the need to take account of the future and its challenges. Here we realize that the humble conscience engages - and sometimes interrupts - our agenda for our lives, which can so easily proceed automatically.

Finally, conscience brings with it a humility that affects not only how we understand our place in God's world but also how we think, learn, and understand. This insight into a humble way of thinking that rejects the imperial ego becomes a relational way of thinking and is complemented by what other theologians call the grace of self-doubt. ${ }^{24}$ In humility we discover that there can be a real grace in doubting ourselves and our opinions. This grace animates and informs our humility and helps us to see that the work of realizing ourselves as disciples of Christ is a formidable lifelong task fraught with misperceptions and yet possible precisely because of that humility.

Humility makes us disposed for a vulnerable mutual recognition, but we also need a second virtue, a willing vigilance so as to actually recognize the precarity of another's situation. Vigilance to the act of recognition is not a simple matter. Philosophers like Paul Ricoeur and Charles Taylor have been writing a great deal from different viewpoints on recognition. Here we can see, for instance, a notable summary of the meanings of recognition:

The term 'recognition' has several distinct meanings: (1) an act of intellectual apprehension, such as when we 'recognize' we have made a mistake

24 Farley, Ethics, Ecclesiology, and the Grace of Self-Doubt, p. 55-77. 
or we 'recognize' the influence of religion on American politics; (2) a form of identification, such as when we 'recognize' a friend in the street; and (3) the act of acknowledging or respecting another being, such as when we 'recognize' someone's status, achievements or rights [...]. The philosophical and political notion of recognition predominantly refers to (3), and is often taken to mean that not only is recognition an important means of valuing or respecting another person, it is also fundamental to understanding ourselves. ${ }^{25}$

Clearly this third type of recognition, "the act of acknowledging or respecting another being, such as when we 'recognize' someone's status, achievements or rights $[. .$.$] " is very important here. Borrowing from Charles Taylor we can see$ that in the context of shared human dignity, due recognition is not then simply a gesture, but rather a need that acknowledges and validates a person or persons long overlooked. ${ }^{26}$ When we fail to give due recognition we often add to the oppression of the other, whose own situation might well be related to our own, though we fail to acknowledge it. Recognition becomes then a moment not only of the other's situation but also my relationship to that other and her or his situation.

This is the recognition of the Good Samaritan who recognizes his neighbor in need (Luke 10:25-37), the recognition of the father of the Prodigal Son who recognizes his son in the distance and rushes to him (Luke 15:11-32), or the recognition of the man born blind who confesses his healer as the Lord (John 9:1-41). These recognitions are enormously important in the Gospels and stand against instances where there is a failure of recognition, as in the older son who only sees his prodigal brother as "this son of yours" and not his brother, the rich man's failure to recognize Lazarus (Luke 16:19-31), the goats failure to recognize the presence of Jesus in the homeless and the hungry (Matthew 25:31-46), or when Jesus wept over the failure of Jerusalem to recognize the time of its visitation (Luke 19:41-44).

This recognition is an illuminating discovery of something or someone that matters enough for us to stop and encounter. There is something like an epiphany that happens, as when Jesus passes by and the blind man cries out Jesus

25 McQueen, Social and Political Recognition.

26 Taylor, The Politics of Recognition, p. 26. See also Pellauer, David and Paul Ricoeur, The Course of Recognition. I am grateful to Hilary Nwainya who introduced me to a paper he delivered in Rwanda this past summer, the yet unpublished Nwainya, Twenty-Five Years after the Genocide. 
have mercy on me a sinner. The blind man senses who it is with authority that is making an appearance (Luke 18:35-43).

Recognition is deeply relational, an awakening in me of something that matters in another. But we need the virtue of vigilance, a readiness to see the world as it actually is, in order to encounter that readiness. In our humility we need to cultivate a vigilance, a mindfulness that we not become as preoccupied as the priest and the Levite in the Good Samaritan, but rather that we are prepared to be prompt to recognize and respond to the neighbor in need.

Humility and vigilance allow us to be merciful: that is to express "the willingness to enter into the chaos of another."27 Here I turn to mercy as a political virtue that moves toward a justice for all, and so I look to Jon Sobrino to see how mercy de-centralizes us by locating us in a new center. Sobrino begins his book on mercy ${ }^{28}$ with an "Introduction" to wake us up from what he calls the "Sleep of Inhumanity." Mercy is first based, he states, not on a commandment but on experience: on recognizing another as precarious, we are moved to respond. That response, Sobrino notes, is a de-centering movement that precedes all others. ${ }^{29}$

Sobrino makes his case for the radical comprehensiveness of mercy through four themes: the principle of mercy, the mercy of God, the mercy of Jesus, and finally, the mercy of the Church. The principle of mercy stands at the origin and basis of all moral activity. He writes: "This principle of mercy is the basic principle of the activity of God and Jesus, and therefore ought to be that of the activity of the church."30

Second, Scripture reveals to us that God is the God of mercy. Sobrino finds in Exodus (3:7-8) that "God stands at the origin of the salvific process." God's activity is mercy: "God hears the cries of the suffering people, and for that reason alone determines to undertake the liberative activity in question. We call this activity of love, thus structured, mercy."31 The mercy of God not only initiates God's activity, it remains the basic constant throughout the Scripture for describing the activity of God.

Third, Sobrino finds in Jesus the expression of the "primordial mercy of God." Repeatedly in his mutual recognition, Jesus internalizes the suffering of another as the first step to his responding: "For Jesus, to be a human being is

\footnotetext{
27 Keenan, The Works of Mercy.

28 Sobrino, The Principle of Mercy.

29 Sobrino, The Principle of Mercy, p. 10.

$30 \quad$ Sobrino, The Principle of Mercy, p. 16.

31 Sobrino, The Principle of Mercy, p. 16.
} 
to react with mercy."32 Bringing these claims together and precisely as he discusses the radicality of mercy, he is finally able to offer a definition of mercy:

Mercy is a basic attitude toward the suffering of another, whereby one reacts to eradicate that suffering for the sole reason that it exists, and in the conviction that, in this reaction to the ought-not-be of another's suffering, one's own being, without any possibility of subterfuge, hangs in the balance. ${ }^{33}$

Fourth, he argues that necessarily "this principle of mercy ought to be operative in Jesus' church." 34 Here Sobrino proposes that the church be the Good Samaritan and allow itself to reposition itself, for to be moved to pity is to shift one's place. As in the Good Samaritan parable, neither the scribe nor the Levite shifted their place; only the Samaritan did. Sobrino writes: "The most important thing is that the church begins to 'think itself' from without, from 'along the road,' where the wounded neighbor lies." When the church emerges from within itself, "it genuinely de-centers itself and thereby comes to resemble Jesus in something absolutely fundamental."35

Mercy therefore is scandalous. It is destabilizing, it causes us to lose our self-understanding, and it dares us to change our course. It causes us, from our vulnerability, to recognize the dignity of another is at risk and that we have to enter into that risky or precarious context for the same of that shared human dignity to secure those human rights.

Through the encounter of mercy we now begin the journey with the fourth and final virtue, hospitality. From the very beginning of his writings, Yiu Sing Lúcás Chan was fascinated with the person of Boaz in the book of Ruth as a model of hospitality for our time. ${ }^{36}$ Living in the United States during his doctoral studies he wrote about the closed-door policies of the industrialized world toward immigrants. He wanted to see why the vulnerable recognition and response to the immigrant is so often culturally inhibited. His retrieval of Boaz is remarkable.

32 Sobrino, The Principle of Mercy, p. 17.

33 Sobrino, The Principle of Mercy, p. 18.

34 Sobrino, The Principle of Mercy, p. 20.

35 Sobrino, The Principle of Mercy, p. 21 et seq.

36 Chan, A Model of Hospitality for Our Times, p. 21-46. Eight years after he wrote his first essay, he revisited his argument again, in Chan, The Hebrew Bible, p. 665-679. 
Reminding us of the line from Homer, "The city which forgets how to care for the stranger has forgotten how to care for itself", ${ }^{37}$ Chan sets the framework:

In the Book of Ruth, the story of Naomi, Ruth - a Moabite and a widow and Boaz, in the time of Judges (around 11th century BCE) is told. Ruth accompanies her mother-in-law, Naomi, back to Judah from Moab. There she meets Boaz, Naomi's husband's relation. At Naomi's insistence, Boaz arranges for the redemption of the family property, and takes Ruth as his wife. Crucial to the story is Ruth's identity as a Moabite widow. Ezra's tirade in Judah, around 458 BCE against community leaders for contracting religiously pernicious marriages with women from the peoples of the lands was quite well known. To be sure, Ezra's position was all of a piece with the postexilic community's objective of keeping its economic holdings intact, that is, resisting even its partial loss to foreign spouses on account of inheritance laws. ${ }^{38}$

In addition to the postexilic community's strong incentive to rebuild itself with the help of Ezra-Nehemiah "separatist policies", there was also the Judean "obsession with ethnicity". Ruth, the Moabite "personifie[d] a country 'stained by incest in their lineage."'39

Chan explains that from the time of the Exodus, the Israelites "harbored a grudge against the Moabites." 40 Moab is situated on what had been the last leg of the Israelites long trek from Egypt to the Promised Land. The Moabites, perceived as unwilling to help, later came to be tagged as the enemy (Deuteronomy 23:3-8). ${ }^{41}$ Against this background comes the evocative multilayered story of accompaniment and hospitality, Ruth's refusal to abandon Naomi, Naomi's coaching of Ruth, Boaz's gentle and faithful recognition and reception of Ruth, his redemption of their debt, and his marriage to Ruth and reception of Naomi.

Chan acknowledges the need to re-pivot Boaz into our understanding of the Book of Ruth. While acknowledging that Boaz's story has been subject to "general scholarly neglect", he points out that Boaz "remains indisputably important to Ruth's and Naomi's story. He serves not only as Naomi's kinsman and a

37 Chan, A Model of Hospitality for Our Times, p. 21.

38 Smith-Christopher, The Mixed Marriage Crisis in Ezra 9-10 and Nehemiah 13, p. 243-265.

39 Chan, A Model of Hospitality for Our Times, p. 21 et seq. On the ethnic obsessions, André Lacocque, Ruth: A Continental Commentary, 2004, p. 26.

40 Chan, A Model of Hospitality for Our Times, p. 22.

41 Lacocque, Ruth, p. 3. 
local paragon of virtue, but also as Ruth's redeemer; he is the conduit to her of God's hesed, providence, and redemptive work." 42 By imitating the hospitable God who brought Israel out of Egypt into the Promised Land, Boaz rejects the injunctions of Ezra and his contemporary collective isolationism, to recognize Ruth and the mercy of God and God's injunction to be hospitable as God has been (Judges 8:4-17).

It is worth noting that Boaz's marriage to the Moabite Ruth is a direct confrontation with the Ezra-Nehemiah insistence on racial purity: Chan writes Boaz's marriage "is remarkable, unconventional and risky." ${ }^{33}$ Chan adds that Boaz stands as an invitation for Israel to think otherwise after "its demoralizing and disorienting experience of the Babylonian exile" and its appropriation of "sectarian, exclusivist impulses."44 Rather than exclude by living in a protectionist world, Israel is called to be humble and vigilant, to be merciful and hospitable.

Sobrino, Chan, and the exemplary Book of Ruth stand as contemporary reminders that through humility, vigilance, mercy, and hospitality we need to de-center not only ourselves but our culture from its own inhibiting intransigence. We see therein the virtues as effective in bringing forth the human vulnerability so rooted in the imago Dei as responsive to the precarity of contemporary human rights.

\section{Biography}

James F. Keenan, S.J., is the Canisius Chair and Director of the Jesuit Institute at Boston College and Vice-Provost for Global Engagement. A Jesuit priest since 1982, he received a licentiate and a doctorate from the Pontifical Gregorian University in Rome. As the founder of Catholic Theological Ethics in the World Church (www.catholicethics.com), he chaired the international conferences in Padua (2006), Trento (2010) and Sarajevo (2018). He has edited or written 25 books and published over 400 essays, articles, and reviews. Recently he wrote University Ethics: How Colleges Can Build and Benefit from a Culture of Ethics and has just finished editing two books, Building Bridges in Sarajevo: The Plenary Papers of Sarajevo 2018 and Street Homelessness and Catholic Theological Ethics. He is presently finishing another book for Paulist Press, A Brief History of Catholic Ethics.

42 Lacocque, Ruth, p. 25.

43 Lacocque, Ruth, p. 31.

44 Lacocque, Ruth, p. 36. 


\section{Bibliography}

Benjamin, Jessica: Beyond Doer and Done to. New York, NY: Routledge, 2017.

Benjamin, Jessica: The Bonds of Love. Psychoanalysis, Feminism, and the Problem of Domination. New York, NY: Pantheon, 1988.

Burggraeve, Roger: The Wisdom of Love in the Service of Love. Emmanuel Levinas on Justice, Peace and Human Rights (Marquette Studies in Philosophy). Milwaukee, WI: Marquette University Press, 2003.

Burggraeve, Roger: The Awakening to the Other. A Provocative Dialogue with Emmanuel Levinas. Leuven: Peeters, 2008.

Butler, Judith: Giving an Account of Oneself. New York, NY: Fordham University Press, 2005 .

Butler, Judith: "Precarious Life, Vulnerability, and the Ethics of Cohabitation", The Journal of Speculative Philosophy 26 (2/2012), p. 134-151.

Butler, Judith: Gambetti, Zeynep/Sabsay, Leiticia (ed.): Vulnerability in Resistance. Durham, NC: Duke University Press, 2016.

Butler, Judith: Precarious Life. The Power of Mourning and Violence. New York, NY: Verso, 2004.

Butler, Judith: Notes toward a Performative Theory of Assembly. Cambridge, MA: Harvard University Press, 2015.

Chan, Yiu Sing Lúcás: “A Model of Hospitality for Our Times”, Budhi: A Journal of Ideas and Culture 10 (1/2006), p. 21-46.

Chan, Yiu Sing Lúcás: "The Hebrew Bible and the Discourse on Migration: A Reflection on the Virtue of Hospitality in the Book of Ruth", Asian Horizons 8 (4/2014), p. 665-679.

Farley, Margaret: "Ethics, Ecclesiology, and the Grace of Self-Doubt", in: James J. Walter, Timothy O'Connell, Thomas A. Shannon (ed.): A Call to Fidelity. On the Moral Theology of Charles E. Curran. Washington, D.C.: Georgetown University Press, 2002, p. $55^{-77}$.

Fleming, Daniel J.: Attentiveness to Vulnerability. A Dialogue between Emmanuel Levinas, Jean Porter, and the Virtue of Solidarity. Eugene, OR: Pickwick Publications, 2019 .

Gilson, Erinn C.: The Ethics of Vulnerability. A Feminist Analysis of Social Life and Practice. New York, NY: Routledge, 2014.

Gilson, Erinn C.: "Thinking Vulnerability with Judith Butler", The Ethics of Vulnerability, p. 40-71.

Haker, Hille: "The Fragility of the Moral Self", The Harvard Theological Review 97 (4/2004), p. 359-381.

Heschel, Abraham: The Prophets. New York, NY: Harper, 1969. 
Hogan, Linda: Keeping Faith with Human Rights. Washington, D.C.: Georgetown University Press, 2015.

Hogan, Linda: "Vulnerability: An Ethic for a Divided World", in: James F. Keenan/ Kristin Heyer/Andrea Vicini (ed.): Building Bridges in Sarajevo. The Plenary Papers of Sarajevo 2018. Maryknoll, NY: Orbis Books, 2019.

Hogan, Linda: "Vulnerability: An Ethic for a Divided World", in: James F. Keenan/ Kristin Heyer/Andrea Vicini (ed.): Building Bridges in Sarajevo. The Plenary Papers of Sarajevo 2018. Maryknoll, NY: Orbis Books, 2019, p. 217-222.

Keenan, James F.: The Works of Mercy. The Heart of Catholicism. Lanham, MD: Rowman and Littlefield, 2005 .

Lacocque, André: Ruth. A Continental Commentary. Minneapolis, MN: Fortress Press, 2004.

LeClerq, Vincent: Blessed Are the Vulnerable. Reaching Out to Those with AIDS. Worcester, MA: Twenty-Third Publications, 2010.

Mackenzie, Catriona/Rogers, Wendy/Dodds, Susan (ed.): Vulnerability. New Essays on Ethics and Feminist Philosophy. New York, NY: Oxford University Press, 2013.

Mathewes, Charles: "Vulnerability and Political Theology", in: Heikke Springhart/ Günther Thomas (ed.): Exploring Vulnerability. Bristol, CT.: Vandenhoeck \& Ruprecht, 2017, p. 165-184.

McCoy, Marina Berzins: Wounded Heroes. Vulnerability as a Virtue in Ancient Greek Literature and Philosophy. New York, NY: Oxford University Press, 2013.

McDonagh, Enda: Vulnerable to the Holy. In Faith, Morality and Art. Dublin: Columbia Press, 2005.

McQueen, Paddy: "Social and Political Recognition", in: The Internet Encyclopedia of Philosophy, https://www.iep.utm.edu/recog_sp/ (date of last access: 20.03.2020).

Nwainya, Hilary: "Twenty-Five Years after the Genocide. Can Rwanda Embrace an Ethics of Recognition?" (forthcoming).

Pellauer, David and Paul Ricoeur: The Course of Recognition. Cambridge, MA: Harvard University Press, 2007.

Smith-Christopher, Daniel: "The Mixed Marriage Crisis in Ezra 9-10 and Nehemiah 13. A Study of the Sociology of the Post-exilic Judean Community", in: Amara Eskenazi/ Kent Richards (ed.): Second Temple Studies, Vol. 2. Temple Community in the Persian Period. Sheffield: Sheffield Academic Press, 1994, p. 243-265.

Sobrino, Jon: The Principle of Mercy. Taking the Crucified People from the Cross. Maryknoll, NY: Orbis, 1994.

Sobrino, Jon: "Awakening from the Sleep of Inhumanity", in: Sobrino, Jon: The Principle of Mercy. Taking the Crucified People from the Cross. Maryknoll, NY: Orbis, 1994.

Sobrino, Jon: "The Samaritan Church and the Principle of Mercy", in: Sobrino, Jon: The Principle of Mercy. Taking the Crucified People from the Cross. Maryknoll, NY: Orbis, 1994. 
Taylor, Charles: “The Politics of Recognition”, in: Amy Gutmann(ed.): Multiculturalism. Examining the Politics of Recognition. Princeton, NJ: Princeton University Press, 1994.

White, T.H.: The Once and Future King. New York, NY: Ace Books, 1987. 